\title{
DAMPAK PENAYANGAN FILM REMAJA DI TELEVISI TERHADAP AKHLAK REMAJA DI KELURAHAN WAY DADI BARU SUKARAME KOTA BANDAR LAMPUNG
}

\author{
Haris Budiman \\ Fakultas Tarbiyah dan Keguruan UIN Raden Intan Lampung \\ haris.budiman@radenintan.ac.id
}

\begin{abstract}
Abstrak
Sering kita saksikan penayangan film remaja di televisi akhir-akhir ini di dalamnya banyak mengandung unsur adegan kekerasan, pornografi dan tata cara pergaulan yang kurang mendidik bagi kaum remaja, terutama pada acara yang ditayangkan stasiun televisi swasta. Penayangana film-film tersebut dapat membawa dampak yang sangat besar terhadap akhlak para pemirsa televisi terutama bagi kaum remaja, karena ingatan mereka pada halhal yang menarik dan disukainya dalam film tersebut dapat menimbulkan kesan yang mendalam dalam jiwanya. Dengan kesan yang mendalam dan tertanam dalam jiwanya mereka berusaha untuk melakukan dan meniru halhal yang mereka anggap menarik seperti apa yang para bintang idolanya lakukan dalam adegan film tersebut. Dengan memperhatikan fenomena tersebut sehingga peneliti ingin tahu lebih banyak tentang bagaimana dampak penayangan film remaja di televisi terhadap akhlak remaja di Kelurahan Way Dadi Sukarame Kota Bandar Lampung. Dalam penelitian ini peneliti menggunakan metode pengumpulan data melalui kuesioner, observasi, interview dan dokumentasi, dan metode teknik sampling. Penelitian ini dilakukan di lingkungan Kelurahan Way Dadi Baru Kecamatan Sukarame Kota Bandar Lampung dengan jumlah populasi sebanyak 230 orang dan sampelnya berjumlah 71 orang remaja yang tersebar dari beberapa Rukun Tetangga (RT) di lingkungan kelurahan tersebut. Setelah data diolah, diedit, diklasifikasi dan diinterpretasi, maka dapat diambil suatu kesimpulan bahwa dampak dari penayangan film remaja yang ditayangkan oleh stasiun televisi swasta terutama yang di dalamnya terdapat adegan kekerasan, pornografi dan lainnya tersebut dapat mempengaruhi akhlak para remaja seperti suka berkelahi, suka begadang sampai larut malam dan perilaku peniruan mulai dari cara berpakaian, tren rambut yang dicat, cara berbicara yang cuek dan lain sebagainya.
\end{abstract}

Kata Kunci: Penayangan Film, Akhlak Remaja 


\section{PENDAHULUAN}

Perkembangan teknologi komunikasi dan informasi telah melahirkan peradaban baru sehingga mempermudah manusia untuk saling berhubungan serta meningkatkan mobolitas sosial kemajuan teknologi elektronik televisi, misalnya telah menyatukan masyarakat dunia dalam informasi dan membuat dunia terasa semakin sempit dan kecil tidak bergerak. Apa yang terjadi ditempat lain dengan cepat diketahuinya di belahan dunia lainnya. Hal ini telah membuktikan analisa (MC. Luhan, 1965). Semakin tinggi kebutuhan manausia akan informasi menyebabkan semakin marak pula kehadiran media informasi, khususnya media televisi.

Lahirnya stasiun-stasiun televisi swasta akhir-akhir ini, baik televisi pemerintah maupun televisi swasta dan bersamaan dengan itu pula maraknya penayangan film nasional maupun internasional banyak mendapat tanggapan dari masyarakat umum maupun masyarakat akademis. Mengenai tanggapan itu ada yang bersifat pro dan ada pula yang bersifat kontra. Bagi mereka yang setuju dengan berbagai macam bentuk penayangan film baik nasional maupun internasional tersebut memandang bahwa pesan yang disampaikan melalui penayangan film tersebut membawa banyak kemajuan bagi kehidupan sosial keagamaan dan sosial kemasyarakatan, sedangkan bagi mereka yang tidak setuju juga mempunyai alasan tersendiri bahwa dengan maraknya berbagai macam film baik nasional maupun internasional pada program siaran televisi banyak membawa pengaruh terutama terhadap akhlak anak dan remaja.

Peranan teknologi dan informasi televisi seperti TVRI, RCTI, ANTV, INDOSIAR, SCTV dan lain-lain bisa mempengaruhi berbagai sendi kehidupan dan salah satu diantaranya adalah kehidupan serta aktivitas sosial keagamaan anak-anak dan remaja. Sebagai konsekuensi dari kemajuan teknologi informasi dan komunikasi, khususnya di bidang pertelevisian tentu saja akan membawa berbagai dampak dalam masyarakat, baik itu dampak positif maupun dampak yang negatif, begitu pula dengan halnya penayangan film di televisi, sebagai pemirsa kita dihadapkan kepada dua pilihan alternatif yaitu dampak positif dan dampak negatif, film yang ditayangkan di televisi tersebut dapat berdampak positif apabila kita menikapinya disertai dengan ideologis yang kritis sehingga pesan simbolis yang ada di dalam tayangan film tersebut disikapi dengan sikap kritis. Sedangkan tayangan-tayangan film tersebut dapat berpengaruh negatif apabila pesan-pesan simbolis yang ada di dalamnya disikapi dengan ideologis rekriatif.

Berdasarkan pengamatan peneliti hal-hal yang masih sering dilakukan para remaja tersebut seperti, model rambut ala punky, kebut-kebutan, bermain gitar sampai larut malam, nongkrong di gardu ronda, dan lain sebagainaya. Terkait dengan fenomena tersebutlah penulis tertarik untuk 
meneliti masalah tersebut, pemilihan tayangan film di televisi sebagai obyek penelitian didasarkan atas makin maraknya perilaku anak-anak dan remaja akhir-akhir ini cendrung tidak sesuai dengan norma-norma keagamaan yang religius. Sebagai populasi dalam penelitian ini penulis mengambil populasi anak remaja usia antara $13-18$ tahun.

\section{LANDASAN TEORI}

\section{Pengertian Televisi}

Keberadaan televisi memang menyenangkan dan dapat bermanfaat bagi masyarakat apabila acara yang ditayangkan banyak berisi tentang informasi pembangunan dan pendidikan, akan tetapi acara yang ditayangkan televisi banyak juga menampilkan acara hiburan yang dapat menimbulkan dampak bagi pemirsanya. Dalam Ensiklopedi umum dikatakan bahwa "Televisi adalah pengiriman gambar dan suara pada saat yang sama dengan implus listrik “. (A.G. Pringgodigno, 1984 : 108).

Sementara menurut pendapat lain mengataakan bahwa "Televisi berasal dari dua kata yang berbeda asalnya, yaitu tele (bahasa Yunani) yang berarti jauh dan visi (vidre bahasa latin) berarti penglihatan. Dengana demikian televisi yang dalam bahasa Inggrisnya television diartikan dengan melihat jauh. Melihat jauh disini diartikan dengan gambar dan suara yang di produksi disuatu temapat (studio televisi) dapat dilihat dari tempat "lain" melalui sebuah perangkat penerima (televisie set). (JB Wahyuni, 1986, 49).

Dengan demikian dapat dipahami bahwa televisi merupakan media audio visual yang dapat menyajikan pesan dengan menampilkan gambar dan suara secara bersamaan, pesan yang dihasilkan telvisi dapat menyerupai benda atau obyek yang sebenarnya atau menimbulkan kesan lain. Oleh karena itu media ini memiliki potensi besar dalam merobah sikap dan perilaku masyarakat.

Sebagai alternatif sumber informasi semacam ini, televisi hampir tidak punya tadingan berarti, antara lain karena efektivitas penyebarannya, pesona gambar dan suaranya serta kemampuan komunikatif yang sempurna. Karena itu siapapun dapat mengambil pelajaran melalui koktak elektronik ini hanya melalui pengorbanan amat kecil, kecuali barangkali waktu. Dengan segala kelebihan ini, tak heran televisi memiliki kemampuan menjual lebih besar dibandingkan media ekspresi lain.

Sayangnya keistemewaan semacam ini kurang diimbangi dengan upaya yang lebih memadai dari berbagai pihak untuk menjadikannya sebagai media informasi sekalipun media hiburan paling edukatif. Yang paling berpengaruh akibat ketidakseimbangan tadi adalah kelompok lemah khalayak televisi di sini adalah kelompok masyarakat terutama yang berada di sektor domestik anak-anak dan remaja. Mereka menjadi pasar sasaran utama terlihat dari tingginya frekwensi tayangan faforit mereka yang disiarkan pada waktu 
milik mereka. Mereka lemah karena sering memperlakukan sajian atelevisi sebagai barang konsumsi kritis, mereka lemah karena paling mudah termakan secondhand impression televisi, yaitu pesan yang diseleksi sedemikian rupa semata berdasarkan selera pribadi produser.

\section{Pembagian Siaran Televisi}

Pada hakekatnya siaran televisi siaran televisi dibagi menjadi dua bagian, yaitu siaran non berita dan siaran berita. Perbedaan antara siaran berita dan non berita dapat dilihat sebagai berikut:

Siaran non berita: Utamakan segi artistiknya, utamakan keindahan, sasaran kepuasan penonton, memenuhi rasa kagum/menghargai seseorang, impropisasi tak terbatas, terkait pada kode moral, scenario seperti pada film, kata-katanya dramatis, refleksi daya hayal kuat, cerita diangkat dari kehidupan masyarakat. Siaran berita utamakan segi jurnalistiknya, terkait dengaan waktu, kepuasan dan kepercayaan penonton, impropvisasi terbatas, terikat dengan kode etik jurnalistik, ekonomi bahasa, ekonomi kata, refleksi pembacaan naskah harus kuat, faktual dan menyerap realitas. (JB Wahyuni, 1980, 13).

Berdasarkan teori teersebut jelaslah bahwa siaran televisi yang bersifat non berita lebih banyak mengutamakan segi keindahan, sehingga dapat dengan mudah diterima oleh khalayak. Begitu juga dengan jenis siaran hiburan terutama film. Film adalah merupakan salah satu siaran non berita yang digemari oleh khalayak pemirsa.

3. Fungsi Televisi

Ada beberapa fungsi televisi sebagaimana yang dikemukakan oleh Edward Sapir, dalam Phil Astrid Susanto meliputi :

a. Mengadakan komunikasi di daerah-daerah yang geografisnya berjauhan;

b. Memungkinkan adanya akulturasi. (Edward Sapir, 1986, 5).

Dengan demikian dapatlah dikatakan bahwa televisi mempunyai fungsi mengadakan komunikasi dengan daerah-daerah yang berjauhan, artinya dengan adanaya siaran televisi maka komunikasi dengan daerahdaerah yang terpencil akan dapat diatasi. Selain itu televisi juga mampu mengatasi jarak dan waktu sehingga para penonton dan pemirsa televisi yang tinggal di daerah terpencil sekalipun dapat menikmati berbagai macam bentuk acara dan siaran yang disuguhkan oleh stasiun televisi.

Selain daripada itu televisi juga mempunyai fungsi memungkinkan adanya akulturasi, artinya percampuran kebudayaan yang berbeda-beda. Televisi juga dapat dijadikan alat untuk menyebarluaskan berbagai macam dan bentuk adat istiadat dan kebudayaan dari seantero bumi nusantara. Sementara menurut pendapat Wilbur Scream, mengemukakan fungsi televisi adalah :

a. The whot man function (fungsi pengawasan);

b. The policy function (fungsi perumus kebijaksanaan); 
c. The teaching function (fungsi pembinaan). (Edward Sapir, 71).

Selain sebagai sarana komunikasi dengan daerah-daerah lain yang jarak geografisnya berjauhan serta memungkinkan adanya akulturasi dengan daerah atau negara lain, televisi juga berfungsi sebagai pengawas. Sebagai pengawas artinya sebagai pengawas segala informasi atau pesan yang akan disampaikan melalui jaringan televisi atau mengawasi kejadian-kejadian yang ada atau yang layak ditayangkan atau disiarkan melalui televisi, seperti ancaman akan terjadinya bencana tsunami, letusan gunung merapi, ancaman serangan militer, kondisi dan keadaan perikonomian dan lain sebagainya

Kemudian fungsi perumus kebijaksanaan, dalam arti memberikan kebijaksanaan demi perkembangan masyarakat tradisional menuju masyarakat modern, sedangkan fungsi pembinaan yaitu dalam arti memberikan pembinaan bagaimana mengatasi berbagai macam masalah dan problem yang dihadapi.

Dengan demikian kita bisa merasakan berbagai macam bentuk dampak yang ditimbulkan oleh adanaya siaran televisi, baik itu dampak dalam bentuk yang positif maupun dampak negatifnya tinggal bagaimana masyarakat menyikapinya.

4. Pengertian Film Remaja

Film adalah "Gerakan, atau lebih tepat lagi gambar yang bergerak. Dalam bahasa Indonesia dahulu dikenal istilah gambar bergerak, dan memang gerakan itulah yang merupakan unsur pemberi hidup pada suatu gambar walaupun teknik yang dipergunakan telah sempurna, tetapi belum mendekati kenyataan hidup sehari-hari, sebagaimana halnya dengan film. Untuk meningkatkan akesan dan adampak dari film, suatu film di iringi dengan suara yang berupa dialog atau musik. Dalam penayangaan suatu film yang baik, dialog dan musik hanya digunakan apabila film tersebut kurang memberi kesan yang jelas kepada pemirsanya, sehingga dialog maupun musik merupakan alat bantu sebagai penganut eksperesi dari para tokoh pemainnya.

Menurut Undang-Undang perfilman No. 6 tahun 1992 mengatakan bahwa "Film adalah karya cipta seni dan budaya yang merupakan media komunikasi massa pandang dengar yang dibuat berdasarkan asas sinematograsi dengan direkam pada pita selulo, pita video, piringan video, dan atau bahan hasil penemuan teknologi lainnya dalam segala bentuk jenis ukuran melalui proses kimia, proses elektronik, atau proses lainnya, dengan atau tanpa suara, yang dapat mempertunjukkan dan atau dibayangkan dengana system proyeksi mekanik, elektronik dan lainnya." (Askurifai Baksin, 2003, 6).

Oleh karena itu dapat disimpulkan bahwa film cara kerjanya yaitu mentransfer lambang-lambang komunikasi lainnya dalam bentuk bayangbayang hidup diatas layar putih. Ini dilakukan atas bantuan proyektor. 
Sedangkan film itu sendiri tidak lain terdiri atas rentetan foto seluloid. Jadi lambang-lambang komunikasi yang bersifat audio visual serta kelihatan hidup pada hakekatnya tidak lain merupakan rentetan dari beribu-ribu foto bergerak dengan peberadaan waktu yang amat akecil. Tiap-tiap foto akan menunjukkan suatu fase dalam proses tertentu dengan bantuan proyektor rentetan foto tersebut akan melebur dan kelihatan hidup sehingga dapat menceritakan kejadian dalam kehidupan manusia, sehingga sama seperti kenyataan yang ada.

Adapun jenis film itu sendiri terdiri atas film cerita (Story film), film berita (news reel), film dokumenter (documentary film), film kartun (cartoon film). (Onong Uchyana Effendi, 1993, 211). Selain daripada itu film juga berfungsi sebagai media komunikasi mengenal pula beberapa fungsi komunikasi yaitu: hiburan, pendidikan, penerangan, mempengaruhi dana sosialisasi. Sedangkan di televisi film merupakan salah satu media komunikasi massa yang mempunyai empat fungsi, yaitu :

a. Menyampaikan informasi (to inform);

b. Mendidik (to educate);

c. Menghibur (to intertain);

d. Mempengaruhi (to influence). (Onong Uchyana Effendi, 2005, 31).

Berdasarkan fungsi film tersebut diatas maka dapat disimpulkan bahwa fungsi film sebagai media komunikasi adalah sebagai hiburan bagi pemirsanya. Rubruk-rubrik huburan sekedar untuk melepaskan saraf-saraf yang tegang setelah banyak beraktivitas, penyebarluasan sinyal, symbol, suara dan citra (image) dari drama, tari, kesenian, kesusastraan, musik, komedi, olah raga, permainan dan sebagainya untuk rekreasi dan kesenangan kelompok dan individu.

Fungsi film untuk mendidik, maksudnya pengalihan ilmu pengetahuan sehingga mendorong perkembangan intelektual, pembentukan watak dan pendidikan ketrampilan serta kemahiran yang diperlukan semua bidang kehidupan. Pendidikan itu tidak hanya diperoleh melalui siaran berita, tetapi film juga sebetulnya mempunyai makna mendidik dan membentuk watak atau perilaku dalam kehidupan.

5. Pengertian Akhlak

Dalam ajaran Islam, akhlak menempati kedudukan yang istimewa dan sangat penting. Akhlak dalam Islam bukanlah sekedar moral yang kondisional dan situasional, tetapi akhlak yang benar-benar memiliki nilai yang mutlak. Nilai-nilai baik dan buruk, terpuji dan tercela berlaku kepada dan dimana saja dalam segala aspek kehidupan, tidak dibatasi oleh waktu dan ruang. Ajaran akhlak dalam Islam sesuai dengan fitrah manusia, manusia akan mendapatkan kebahagian yang hakiki, bukan semu, bila mengikuti nilai-nila kebaikan yang diajarkan oleh Al-Qur,an dan Sunnah, dua sumber 
akhlak dalam Islam. Akhlak dalam Islam benar-benar memelihara eksistensi manusia sebagai makhluk yang terhormat yang sesuai dengan fitrahnya.

Secara etimologis Akhlak (bahasa Arab) adalah bentuk jamak dari khulug yang berarti budi pekerti, perangai, tingkah laku atau tabi'at. Berakar dari kata khlaqa yang berarti menciptakan. Seakar dengan kaqta khaliq (pencipta), makhluk (yang diciptakan) dan Khalq (penciptaan).

Kesamaan akar kata tersebut mengisyaratkan bahwa dalam akhlak tercakup pengertian terciptanya keterpaduan antara kehendak Khaliq (Tuhan) dengan perilaku makhluq (manusia). Atau dengan kata lain tata perilaku seseorang dengan orang lain dan lingkungannya baru mengandung nilai akhlak yang hakiki manakala tindakan atau perilaku tersebut didasarkan kepada kehendak Khalik (Tuhan). Sesungguhnya sumber dari akhlak itu tidak lain dari Al-Qur'an dan Sunnah Rasulullah SAW (Al-Hadits), serta hasil dari pemikiran manusia dan filosof.

Adapun ayat yang menerangkan akhlak terdapat dalam surat AlQalam ayat 4 yang berbunyi :

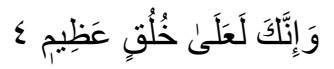

Artinya : "Dan sesungguhnya kamu benar-benar berbudi pekerti yang agung”.(Departemen agama RI, 1984, 908).

Dari apa yang atelah ditegaskan oleh Al-Qur'an dan hadis tersebut jelaslah bahwa segala perilaku manausia yang mengaku dirinya seoranag yang beragama Islam haruslah dapat menterjemahkan kedua sumber tersebut dalam kehidupan sehari-hari. Akhlak merupakan cerminan bagi orang Islam sebagimana yang telah dicontohkan oleh Nabi Muhammad SAW. Hal ini dijelaskan dalam Al-Qur'an surat Al-Ahzab ayat 21 yang berbunyi :

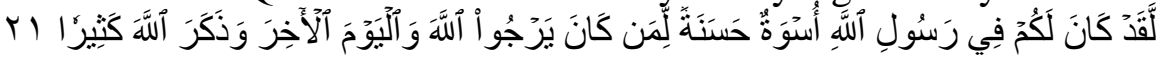

Artinya : "Sesungguhnya telah ada pada (diri) Rasulullah itu suri teladan yang baik bagimu (yaitu) bagi aorang yang mengharap (rahmat) Allah dan (kedatangan) hari kiamat daan dia banayak menyebut Allah (Departemen agama RI, 1984, 1001).

Merujuk dari ayat tersebut dapat diambil suatu akesimpulan bahwa ajaran agama Islam yanga disampaikan oleh Nabi Muhammad SAW akan melahirkan akhlak mulia(baik) secara sempurna. Dengana demikian orang yang mengharapkan pahala dikemudian hari maka ia harus mengingat Allah SWT.

Dari pengertian etimologis seperti ini, akhlak bukan saja sebagai tata aturan atau norma perilaku yang mengatur hubungan antar sesama manusia, 
tetapi juga norma yang mengatur hubungan antara manusia dengan Tuhan dan bahkan dengan alam semesta.

\section{Sumber Akhlak}

Dalam konsep akhlak, segala sesuatu itu dinilai baik atau buruk, terpuji atau tercela, semata-mata karena Syara' (Al-Qur'an dan Sunnah). Kenapa sifat sabar, syukur, pemaaf, pemurah dan jujur misalanaya dinilai baik? Tidak lain karena Syara' menilai semua ssifat-sifat itu baik. Begitu pula sebaliknya, kenapa pemarah, tidak bersyukur, dendam, kikir dan dusta misalnya dinilai buruk? Tidak lain karena Syara' menilainya demikian. Mengapa sifat sabar, syukur, pemaaf, pemurah dan jujur misalnya dinilai baik? Tidak lain karena Syara' menilai semua sifat-sifat itu baik. Begitu pula sebaliknya, kenapa pemarah, tidak bersukur, dendam, kikir, dan dusta misalnya dinilai buruk? Tidak lain karena Syara' menilainya demikian.

Hati nurani atau fitrah dalam bahasa Al-Qur'an memang dapat menjadi ukuran baik dan buruk karena manausia diciptakan oleh Allaah SWT memiliki fitrah bertauhid, mengakui ke-Esaan-Nya(QS. Ar-Rum 30:30). Karena fitrah itulah manusia cinta akepada kesucian dan selalu cenderung kepada kebenaran. Hati nuraninya selalu mendambakan dan merindukan kebenaran, ingin mengikuti ajaran-ajaran Tuhan, karena kebenaran itu tidak akan didapat kecuali dengan Allah sebagai sumber kebenaran mutlak. Namun fitrah manusia tidak selalu terjamin dan berfungsi dengan baik karena pengaruh dari luar, misalnya pengaruh pendidikan dan lingkungan sekitar. Fitrah hanyalah merupakan potensi dasar yang perlu dipelihara dan dikembangkan, betapa banyak manusia yang fitrahnya tertutup sehingga hati nuraninya tidak dapat lagi melihat kebenaran. Oleh sebab itu ukuran baik dan buruk tidak dapat diserahkan sepenuhnya hanya kepada hatia nurani atau fitrah manausia semata melaiankan harus dikembalikana kepada penilaian Syara'. Semua keputusan Syara' tidak akan bertentangan dengan hati nurani manausia, karena keduanya berasal dari sumber yang sama yaitu Allah SWT.

2. Tujuan Akhlak

Tujuan akhlak adalah: "Supaya dapat terbiasa melakukan yang baik, indah, mulia atau terpuji serta menghindari yang buruk, tercela dan hina."(Ismail Tharib, 1984, 2).

Sedangkan akhlak menurut Mustafa Zuhri, beliau mengatakan bahwa tujuan mempelajari akhlak adalah: "Untuk membersihkan qalbu dan kotorankotoran hawa nafsu dan amarah sehingga suci, bersih, bagaikan cermin yang mampu menerima nur cahaya Tuhan. (Solihin dan Rosihon Anwar, 2005, $62)$.

Dari kedua pendapat tersebut maka dapat disimpulkan bahwa tujuan akhlak agar manusia terbiasa melakukan perbuatan yang baik serta menghindari perbuatan yang buruk. Artinya perbuatan buruk atau tercela itu harus kita hindari dengan menjauhi sifat yang buruk, perbuatan yang dapat 
membuat manusia menjadi hina, baik dihadapan manusia maupun dihadapan Allah SWT. Seperti melakukan perbuatan zina, berkata tidak sopan dan sebagainya, karena perbuatan itu tidak sesuai dengan norma atau hukum Islam yang berdasarkan Al-Qur'an dan Hadits.

3. Macam-Macam Akhlak

Akhlak dalam Islam bukanlah moral yang kondisional dan situasional, tetapi akhlak yang benar-benar memiliki nilai yang mutlak, nilai-niali yang baik dan nilai-nilai yang buruk, terpuji dan tercela berlaku kapan dan dimana saja dalam segala aspek kehidupan, tidak dibatasi oleh ruang dan waktu.

Dalam keseluruhan ajaran Islam, akhlak menempati kedudukan yang istimewa dan sangat penting. Dalam Al-Qur'an saja ditemui lebih kurang 1.500 ayat yang berbicara tentang akhlak dua setengah lebih banyak daripada ayat-ayat tentang hukum baik yang teoritis maupun yang praktis. Belum terhitung lagi hadits-hadits Nabi, baik perkataan maupun perbuatan yang memberikan pedoman akhlak yang mulia dalam seluruh kehidupan umat manusia.

Ajaran akhlak dalam Islam sesuai dengan fitrah manusia, manusia akan mendapatkan kebahagiaan yang hakiki, bukan semu bila mengikuti nilai-nilai kebaikan yang diajarkan oleh Al-Qur'an dan Sunnah, dua sumber akhlak dalam Islam. Akhlak dalam ajaran Islam benar-benar memeliharaa eksistensi manusia sebagai makhluk terhormat dan yang sesuai dengan fitrahnya.

Tujuan hidup seseorang yang beragama adalah mencapai kesejahteraan di akhirat, khusus bagi umat Islam dalam kehidupan ini tentunya manausia dalam bertindak dan berbuat bermacam-macam cara dan tingkah laku mereka yang lakukan, baik yang berhubungan langsung dengan Allah SWT maupun dengan manausia. Dalam berinteraksi antar sesama manausia dituntut agar saling tolong menolong dalam hal kebajikan, berbuat baik kepada sesama manusia dan kesemuanya itu merupakan tindakan terpuji yang harus dimiliki oleh setiap manusia.

Dengana demikian jelaslah bahwa perbuatan manusia yang baik adalah merupakan akhlaak ayang wajib dikerjakan, sedangakan perbuatan yang buruk harus kita tinggalkan, dan itulah yang menunjukan akhlak kita baik atau buruk. Menurut pembagiannya, akhlak dapat dibagi menjadi dua bagaian yaitu :

1. Akhlak terpuji (Al-Akhlak Al-Mahmudah);

2. Akhlak tercela (Al-Akhlak Madzmumah).

Menurut Al-Ghazali, berakhlak mulia atau terpuji artinya : "Menghilangkan semua adat kebiasaan yang tercela yang sudah digariskan dalam agama Islam serta menjauhkan diri dari perbuatan tercela tersebut, kemudian membiasakan adat kebiasaan yang baik, melakukannya dan mencintainya" (Zahrudin dan Hasanudin Sinaga, 2004, 158). 
Sedangkan menurut Abdul Karim Zainudin, mengatakan baahwa akhlak adalah "(Akhlak) adalah nilai-nilai dan sifat-sifat yang tertanam dalam jiwa, yang dengan sorotan dan timbangannya seseoranag dapat menilai perbuatannya baik atau buruk, untuk kemudian memilih melakukan atau meninggalkannya". (H. Yunahar Ilyas, 2012, 2).

Dari kedua pendapat tersebut dapat dikatakan bahwa akhlak atau khuluq itu adalah sifat yang tertanam dalam jiwa manusia sehingga dia akan muncul secara spontan bilamana diperlukan tanpa memerlukan pemikiran atau pertimbangan lebih dahulu, serta tidak memerlukan dorongan dari luar.

Akhlak yang terpuji dibagi menjadi dua bagian yaitu :

1. Taat Lahir, meliputi:

a. Tobat;

b. Amar Ma'ruf Nahi Munkar;

c. Syukur.

2. Taat Batin, meliputi:

a. Tawakal;

b. Sabar;

c. Qona'ah (Zahrudin dan Hasanudin Sinaga, 2004, 159).

Dari beberapa keterangan tersebut dapat disimpulkan bahwa akhlak yang baik itu bukan hanya perbuatan yang nampak saja, akan tetapi antara sikap dan perbuatan bisa menyatu antara lahiriah dan batiniah.

\section{METODE PENELITIAN}

1. Jenis Penelitian

Jenis penelitian yang penulis gunakan yaitu penelitian deskriptif dengan menggunakan metode kualitatif. Penelitian deskriptif yaitu jenis penelitian yang menggambaarkan kodisi senyata-nyatanya berdasarkan data yang terhimpun di lapangan. Penelitian deskriptif yaitu jenis penelitian yang menggambarkan kondisi nyata berdasarkan data yang didapat di lapangan. Penelitian deskriptif mempelajari permasalahan yang terjadi sebagaimana adanya, berdasarkan hal tersebut maka penelitian ini bertujuan :

a. Mengamati orang dalam lingkungan hidupnya;

b. Berinteraaksi dengan mereka;

c. Berusaha memahami bahsa dan tafsiran mereka tentang dunia sekitar;

d. Mengungkapkan segala sesuatu yang sedang berlanagsung secara resmi. ( S. Nasution, 1996, 6).

2. Metode Penelitian

a. Populasi

Menurut Suharsimi Arikunto, populasi adalah keseluruhan subyek penelitian. (Suharsimi Arikunto, 2006, 130). Sedangkan menurut M. Iqbal Hasan, populasi adalah totalitas dari semua obyek/individu yang memiliki 
karateristik tertentu, jelas dan lengkap yang akan diteliti. (M. Iqbal,2002, 58). Berdasarkan kedua pendapat tersebut dapat disimpulkan bahwa populasi merupakan keseluruhan wilayah/obyek atau subyek penelitian yang memiliki karateristik tertentu.

Populasi dalam penelitian ini adalah kaum remaja yang ada di Kelurahan Way Dadi Baru Sukarame Bandar Lampung. Sedangkan populasi dalam penelitian ini adalaha remaja usia 13 - 18 tahun yang berjumlah 230 orang.

\section{b. Sampel}

Sampel adalah sebagian atau wakil dari populasi yang diteliti (M. Iqbal, 131). Sedangkan menurut M. Iqbal Hasan sampel adalah bagian dari populasi yang diambil melalui cara-cara tertentu yang juga memiliki karateristik tertentu, jelas, dan lengkap yang akan diteliti. ( M. Iqbal, 59).

Dengan demikian dapatlah dikatakan bahwa sampel merupakan bagian atau wakil dari jumlah dan karateristik yang dimiliki oleh populasi. Untuk menentukan besar kecilnya sampel peneliti berpedoman pada pendapat Suharsimi Arikunto yang menyatakan sebagai berikut "Untuk sekedar ancerancer maka apabila jumlah subyeknya kurang dari 100, lebih baik diambil semua, tetapi jika jumlah subyeknya besar maka dapat diambil antara $10-15$ $\%$ atau $20-25 \%$ atau lebih." (Suharsimi Arikunto, 134).

Memperhatikan pendapat dan ketentuan tersebut peneliti menetapkan mengambil sampel sebesar $15 \%$ dari jumlah populasi sebanyak 230 remaja yang tersebar dari bebarap RT yang ada di lingkungan Kelurahan Way Dadi Baru Sukarame Bandar Lampung.

Tabel 3

Distribusi Sampel

\begin{tabular}{|c|c|c|c|c|}
\hline No. & RT & Jumlah Populasi & $\%$ & $\begin{array}{c}\text { Jumlah } \\
\text { Sampel }\end{array}$ \\
\hline 1 & 01 & 30 & 30 & 9 \\
\hline 2 & 02 & 30 & 30 & 9 \\
\hline 3 & 03 & 30 & 30 & 9 \\
\hline 4 & 04 & 35 & 30 & 11 \\
\hline 5 & 05 & 35 & 30 & 11 \\
\hline 6 & 06 & 35 & 30 & 11 \\
\hline 7 & 07 & 35 & 30 & 11 \\
\hline & Jumlah & 230 & & 71 \\
\hline
\end{tabular}

3. Sumber Data

Dalam penelitian ini data akan digali melalui dua sumber, yaitu sumber data primer dan sumber data sekunder, yang meliputi : 
a. Sumber Data Primer

Sumber data primer adalah data yang diperoleh dari sumber utama secara langsung dari lapangan.

b. Sumber Data Sekunder

Selain data primer seperti di atas yang penulis gunakan juga diperlukan sumber data sekunder. Sumber data sekunder adalah data yang diperoleh dari sekunder/kedua yang akan digali melalui aparat pemerintah Kelurahan Way Dadi Baru dan juga dari masyarakat yang ada di sekitar lokasi penelitian.

4. Teknik Pengumpulan Data

Dalam penelitian ini, teknik pengumpulan data yang akan peneliti gunakan metode sebagai berikut :

a. Metode Kuesioner

Kuesioner adalah dengan cara mengajukan sejumlah pertanyaan tertulis yang digunakan untuk memperoleh informasi dari responden dalam arti laporan tentang pribadinya atau hal-hal yang ia ketahui. (Suharsimi Arikunto, 2006, 71).

b. Interview

Interview merupakan cara yang digunakan untuk mendapaatkan data dengan cara melakukan wawancara/tanya jawab langsung pada informan dan responden.

c. Observasi

Observasi yaitu dengan cara mengadakan pengamatan dan mencatat secara sistematis terhadap gejala/peristiwa yang tampak pada obyek penelitian.

d. Dokumentasi

Dokumentasi yaitu metode yang digunakan untuk mengumpulkan berbagai macam dan bentuk dokumen yang dianggap perlu dan yang berkaiatan dengan masalah yang akan diteliti.

5. Metode Analisa Data

Data yang terkmpul masih merupakan data mentah, yang berarti data tersebut masih perlu diolah dan dianalisa sehingga menghasilkan suatu kesimpulan yang dapat digunakan sebagai bukti kebenaran atau penolakan dari hepotesis yang diajukan. Dalam penelitian ini ada dua jenis data yang diperoleh yaitu data yang bersifat kualitataif dan kuantitatif. Dalam menganalaisa data peneliti menggunakan analisis data yang bersifat deskriptif yaitu data yang bersifat kualitatif digambarkana dengan kata-kata atau kalimat dipisah-pisahkan menurut kategoriuntuk memperoleh kesimpulan selanjutnya, untuk data yang bersifat kuantitatif berwujud angka hasil perhitungan atau pengurangan di proses dengan cara menjumlahkan, membandingkan dengan jumlah diharapkan untuk memperoleh persentase, lalu ditafsirkan dengan kalimat kualitatif. 
Adapun langkah-langkah yang ditempuh dalam pengolahan data sebagai berikut :

a. Editing, yaitu mengumpulkan semua data yang diperlukan;

b. Klasifikasi, yaitu mengelompokkan dan mengklasifikasi data;

c. Tabulasi, menghitung persentase jawaban dan disusun dalam abentuk tabel.

Rumus yang digunakan dalam menghitung persentase jawaban adalah sebagai berikut :

$$
\mathrm{P}=\frac{\text { hasil jawaban } \times 100 \%}{\text { Jumlah Sampel }}
$$

d. Interpretasi; dari analisis diambil kesimpulan berdasarkan pada jawaban yang persentasenya terbanyak sebagai dasar penentuan kesimpulan dalam penelitian.

\section{PEMBAHASAN}

Tidak diragukan lagi bahwa televisi merupakan suatu alat yang canggih dan telah menyebar luas ke berbagai pelosok tanah air dan berbagai lapisan masyarakat khususnya masyarakat Indonesia. Dengan bermunculannya stasiun-stasiun televisi swasta akhir-akhir ini masyarakat mendapatkan banyak informasi tentang berbagai macam bentuk kajadian dan peristiwa yang terjadi baik didalam maupun diluar negeri. Selain daripada itu televisi juga berfungsi sebagai sumber untuk mendapatkan informasi pendidikan, televisi juga memiliki fungsi hiburan. Hiburan yang dihadirkan di layar televisi dapat berupa musik, film, olah raga, berita dan lain-lain. Dalam hal ini hiburan dan program acara yang sering ditayangkan di layar televisi sebagian besar adalah film, dalam hal ini adalah film remaja, dan kebanyakan film-film yang di produksi tanpa memperhatikan isi dan kualitas film, karena di samping terdapat sisi positif film juga banyak mengandung sisi-sisi negatif.

Dampak penayangan film remaja di televisi tidak saja merupakan maslah yang sedang dihadapi oleh masyarakat khususnya kaum remaja di Kelurahan Way Dadi Baru Sukarame Bandar Lampung tetapi juga oleh lingkungan dan masyarakat lainnya. Khusus bagi kaum remaja Kelurahan Way Dadi Baru terlihat bahwa penayangan film remaja yang ditayangkan stasuin televisi juga tidak terlepas dari dampak yang ditimbulkannya. Dampak-dampak tersebut terlihat dari segi penampilan berbusana, gaya rambut, cara berbicara, suka begadang sampai larut malam dan lain-lain itu sesungguhnya tidak mencerminkan perilaku keagamaan kaum remaja dan tentu saja hal tersebut bertentangan dengan akhlak dan sopan santun yang tumbuh ditengah-tengah masyarakat.

Berikut ini peneliti cantumkan tabel pilihan remaja terhadap tema cerita film remaja yang disukai atau digemari : 
Tabel 5

Pilihan Remaja Terhadap Tema Cerita

Film Remaja Yang Disukai

\begin{tabular}{|l|l|l|l|}
\hline No. & \multicolumn{1}{|c|}{ Tema Film } & Stasiun TV & $\begin{array}{l}\text { Waktu } \\
\text { Tayang }\end{array}$ \\
\hline 1 & Kesempurnaan Cinta & NET & 17.00 \\
\hline 2 & Kelas Internasional & NET & 18.00 \\
\hline 3 & Anak Langit & SCTV & 19.45 \\
\hline 4 & Si Buluk Jatuh Cinta & SCTV & 07.55 \\
\hline 5 & Nathan \& Nadia & Trans TV & 18.00 \\
\hline 6 & Jodoh Wasiat Bapak & AN TV & 07.30 \\
\hline 7 & Cantik-cantik Kucing Dapur & AN TV & 22.00 \\
\hline 8 & Ana Cinta Sejatiku & Global TV & 13.00 \\
\hline 9 & ABC (Awas Banyak Copet ) dll. & Global TV & 11.30 \\
\hline
\end{tabular}

Sumber : Website masing-masing stasiun televisi yang bersangkutan

Tabel 6

Pilihan Remaja Terhadap Film Cerita

\begin{tabular}{|l|l|c|c|}
\hline No & \multicolumn{1}{|c|}{ Tema Film Remaja } & F & $\%$ \\
\hline 1 & $\begin{array}{l}\text { Seks, drama percintaan, rumah } \\
\text { tangga }\end{array}$ & 30 & 42,25 \\
\hline 2 & $\begin{array}{l}\text { Cara berpakaian, gaya rambut, } \\
\text { action }\end{array}$ & 35 & 49,30 \\
\hline 3 & Pendidikan, keagamaan & 6 & 8,45 \\
\hline
\end{tabular}

Sumber : Data kuesioner tanggal, 13 September 2017

Dari tabel tersebut dapat dilihat bahwa para remaja yang suka menonton film remaja khususnya cara berpakaian dan gaya rambur lebih dominan bila dibandingkan dengan acara film yang lain.

Berikut ini tabel frekuensi remaja menonton film dalam satu minggu. 
Tabel 7

Frekwensi Remaja Menonton Film

Dalam Satu Minggu

\begin{tabular}{|l|l|c|c|}
\hline No. & \multicolumn{1}{|c|}{ Tema Cerita Film } & F & $\%$ \\
\hline 1 & $\begin{array}{l}\text { Lima kali atau lebih dalam 1 } \\
\text { minggu }\end{array}$ & 57 & 80,28 \\
\hline & Tiga kali atau lebih dalam 1 minggu & 9 & 12,67 \\
\hline 3 & Dua kali atau lebih dalam 1 minggu & 5 & 7,04 \\
\hline
\end{tabular}

Sumber : Data kuesioner tanggal, 13 September 2017

Memperhatikan data tersebut dapat disimpulkan bahwa kaum remaja yang suka menonton film remaja sebanyak 5 kali atau lebih dalam satu minggu sebanayak 57 orang atau mencapai $80,28 \%$, yang frekwensi menonton 3 kali atau lebih dalam satu minggu sebanyak 9 orang atau mencapa $5,7 \%$ dan terahir yang menonton film remaja 2 kali atau lebih dalam satu minggu hanya 5 orang, atau mencapai $7,04 \%$. Dengan demikian dapat dilihat bahwa frekwensi tertinggi dari 57 orang remaja atau 80,28\% menonton film di televisi $5 \mathrm{kali}$ atau lebih dalam seminggu.

Berdasarkan hasil wawancara dengan ibu Evi Wijayanti, S.E., selaku Kasi Pemerintahan dan pembangaunan di Kelurahan Way Dadi Baru mengatakan baahwa: "Warga kami di sini boleh dikatakan semua sudah memiliki yang namanya televisi, sebab saat ini barang elektronik seperti televisi bukan lagi termasuk barang mewah jadi warga kami tidak asing lagi dengan namanya televisi tersebut bahkan ada dan sudah banyak beberapa warga kami yang dalam satu rumah itu sudah banyak yang memiliki televisi lebih dari satu buah dan itu tidak aneh lagi sudah biasa saja begitu. (hasil wawancara dengan bapak Sugeng Waloyo pada tanggal, 14 September 2017).

Begitu pula hasil wawancara peneliti dengan salah seorang tokoh masyarakat di Kelurahan Way Dadi Baru yaitu Bapak Marwoto beliau juga mengatakan bahwa "hampir dipastikan kalau di lingkungan masyarakat di sini semua sudah memiliki dan mempunyai televisi bahkan banyak yang sudah memiliki televisi lebih dari satu buah." (hasil wawancara dengan bapak Marwoto pada tanggal, 14 September 2017).

Memperhatikan hasil wawancara peneliti dengan masyarakat di sekitar Kelurahan Way Dadi Baru dapat dikatakan bahwa mereka menganggap kalau televisi merupakan suatu kebutuhan dan dikarenakan televisi merupakan salah satu sarana hiburan yang dapat dinikmati baik oleh anak-anak, remaja dan bahkan orang tua sebab kita tidak perlu repot-repot lagi keluar rumah untuk menonton film, baik itu film remaja, film khusus untuk anak-anak ataupun untuk orang dewasa sekalipun, sebab hampir 
seluruh stasiun televisi mempunyai program acara siaran unggulan yang menarik dan bersaing antara stasiun televisi yang satu dengan stasiun televisi yang lainnya.

Tidak jauh berbeda pendapat dari ibu Nurhayati, beliau mengatakan bahwa "sesungguhnya para remaja menonton film remaja di televisi tanpa memperhatikan apakah film tersebut sifatnya menarik ataupun tidak mendidik yang peenting bagi mereka bisa menyaksikan tokoh idolanya dalam film tersebut itupun bagi mereka sudah cukup puas". (hasil wawancara peneliti dengan ibu Nurhayati pada tanggal, 16 September 2017).

Berdasarkan hasil wawancara dan pendapat dari masyarakat tesebut dapat diambil suatu kesimpulan bahwa televisi telah dijadikan sebagai kebutuhan pokok dan mereka telah terbiasa menonton televisi telah dijadikan sebagai sarana hiburan terutama dengan kehadiran film remaja. Para remaja telah terbiasa menyaksikan film di televisi tanpa memperhatikan apakah film yang ditonton itu bersifat mendidik atau hanya sebagai sarana hiburan tanpa memperhatikan segi manfaat atau akibat dikemudian hari. Penayangan film remaja di televisi terutama film-film remaja yang banyak menampilkan adegan kekerasan, pornografi, model dan cara berpakaian, cara berbicara yang cuek dan acuh tentu semua itu mempunyai dampak terhadap akhlak para remaja, selain itu film remaja yang ditayangkan juga mempunyai dampak peniruan, artinya pemirsa dihadapkan pada tren aktual, seperti model pakaian, model rambut dan cara berbicara ala anak gaul sering di ikuti dan di contoh oleh para remaja dalam kehidupan dan pergaulan mereka sehari-hari.

Demikian pula halnya berdasarkan hasil wawancara dengan Bapak Supi,I selalu tokoh agama mengatakan bahwa "Pemilik televisi di Kelurahan Way Dadi Baru boleh dikatakan sudah merata baik itu pada kalangan miskin maupun kaya, hal ini dikarenakan televisi merupakan suatu sarana hiburan yang dapat dinikmati oleh semua orang, baik bagi anak-anak, remaja mapun orang dewasa. Sedangkan penonton televisi rata-rata adalah kaum remaja, baik remaja awal maupun bagi remaja akhir karena mereka menyukai segala macam bentuk film remaja baik itu film drama lokal maupun non lokal". (hasil wawancara peneliti tanggal, 17 September 2017).

Berdasarkan hasil wawancara peneliti dengan beberapa orang baik itu sebagai tokoh masyarakat maupun dari aparat Kelurahan Way Dadi Baru dapat diambil suatu kesimpulan bahwa pada dasarnya televisi telah dijadikan sebagai sarana hiburan dan pendidikan serta keagamaan bagi warga dan masyarakat terutama dengan begitu banyaknya pilihan acara yang di tayangkan oleh beberapa stasiun televisi saat ini. Khusus bagi kaum remaja mereka telah terbiasa menyaksikan film di televisi tanpa memperhatikan apakah film yang di tonton sifatnya mendidik atau hanya sebagai sarana hiburan tanpa memperhatikan apakah film yang di tonton tersebut ssifatnya mendidik atau hanya sebagai hiburan tanpa mengambil manfaatnya. 
Film remaja yang ditayangkan di televisi banyak yang mengandung adegan kekerasan dan pornografi tentu memiliki dampak terhadap akhlak para remaja, karena dengan menonton film di televisi para remaja dapat menambah wawasan dan pengetahuan dari film yang mereka saaksikan di televisi, baik itu dampak yang bersifat possitif maupun dampak negatif. Selain itu film juga menimbulkan damapak peniruan, artinya pemirsa dihadapkan pada treni aktual seperti model pakaian, model rambut ala punk, cara berbicara yang ceplas ceplos, hal-hal tersebut yang sering diikuti dan dicontoh oleh para kaum remaja sehingga menimbulkan dampak perilaku yaitu tertanamnya nilai-nilai budaya yang ditayangakan pada film remaja di telvisi yang sering di terapkan dalam kehidupan kaum remaja dalam pergaulan sehari-hari.

Berdasarkan hasil observasi yang peneliti temukan bagi para remaja di lingkungan Kelurahan Way Dadi Baru ada beberapa dampak negatif yang ditimbulkan dari film-film remaja yang sering disaksikan para kaum remaja dimana bayak dianatara mereka yang memiliki perilaku atau akhlak yang kurang terpuji seperti mempunyai sifat peniruan baik dari segi berpakaian, model rambut yang dicat, cara berbicara, suka begadang sampai larut malam dan lain sebagainya.

Hasil wawancara peneliti dengan saudara Eko salah satu remaja di Kelurahan Way Dadi Baru mengatakan bahwa " Saya sering merubah bentuk dan warna rambut hal tersebut saya lakukan untuk menyesuaikan diri dalam pergaulan saya dan teman-teman saya, sebab berdasarkan pengamatan saya sewaktu menonton film remaja di televisi dengan meniru gaya rambut yang dicat itu membuat saya lebih mudah menyesuaikan diri dalam pergaulan saya sehari-hari." (hasil wawancara peneliti pada tanggal 21 September 2017).

Sedangkan hasil wawancara peneliti dengan saudara Fernando juga salah satu remaja yang tinggal di Kelurahan Way Dadi Baru, mengatakan bahwa " saya sering menyaksikan film remaja di televisi dimana para pemainnya rata-rata penampilan mereka sangat keren karena rambutnya dicat, pakaian dengan model-model masa kini, sehingga membuat saya dan temean-teman remaja yang lain ikut meniru gaya mereka seperti yang kami saksikan di layar televisi membuat kami terpengaruh dan ingin meniru gaya mereka dan itu keren." (hasil wawancara peneliti pada tanggal, 22 September 2017).

Sedangkan hasil wawancara peneliti dengan salah seorang staf Kelurahan Way Dadi Baru, yaitu ibu Meiliyana, S.P., beliau mengatakan bahwa "Televisi khususnya film remaja yang di tayangkan di stasiun televisi sedikit banyak dapat mempengaruhi perkembangan jiwa para remaja, hal tersebut dapat dilihat dari perilaku mereka sehari-hari, akan tetapi menurut pengamatan saya apa yang mereka tiru dan lakukan sebetulnya tidaklah terlalu mengkhawatirkan hal ini dikarenakan mereka rata-rata masih sekolah 
jadi masih ada lah batas-batasnya, dan itu masih termasuk dalam hal yang wajar namanya juga anak-anak remaja." (Wawancara peneliti pada atanggal, 23 September 2017).

Memperhatikan dari beberapa hasil wawancara yang peneliti lakukan baik terhadap tokoh agama, tokoh masyarakat, aparat kelurahan maupun terhadap para remaja yang bersangkutan dapat disimpulkan bahwa tidak dipungkiri bahwasanya film-film remaja yang ditayangkan pada program siaran di stasiun televisi saat ini memang sedikit banayak membawa pengaruh terhadap perilaku dan sikap kaum remaja, baik itu pengaruh yang sifatnya negatif maupun yang sifatnya positif. Hal-hal akibat pengaruh yang negatif yang sangat menonjol yaitu dari segi peniruan, dalam hal ini para remaja sering meniru tingkah laku para pemain di film tersebut dengan tanpa memperhatikan baik dan buruk serta akibat yang timbul di kemudian hari.

\section{SIMPULAN}

Berdasarkan hasil pembahasan, pengolahan data dan analisa data dapat diambil suatu kesimpulan sebagai berikut :

1. Film remaja yang banyak mengandung adegan kekerasaan dan pornografi yang ditayangkan pada acara televisi tentu memiliki dampak positif dan dampak negatif terhadap akhlak para remaja di lingkungan Kelurahan Way Dadi Baru Sukarame Bandar Lampung;

2. Dampak positif dari penayangan film remaja di televisi adalah dapat menambah wawasan dan pengetahuan bagi para remaja untuk dapat mencontoh dan mengikuti perilaku yang terpuji dan lebih baik dari para tokoh dan pemain dalam film tersebut;

3. Dampak negatif yang timbul dari penayangan film remaja tersebut seperti adegan kekerasan dan pornografi bagi para remaja tersebut lebih cendrung memiliki sikap peniruan terhadap perilaku dari para tokoh dan pemain idola mereka seperti perilaku yang kasar, suka berkelahi, cara berpakaian, suka begadang sampai larut malam, model rambut yang dicat, cara dan gaya berbicara yang ceplas ceplos dan perilaku semacam ini sering terbawa-bawa dalam pergaulan mereka sehari-hari. 


\section{DAFTAR PUSTAKA}

Ali Abdul Hakim, Akhlak Mulia, Gema Insani Press, Jakartya, 2004; Andi Mappiare, Psikologi Remaja, Usaha Nasional, Surabaya, 1982;

Askurifai Baksin, Membuat Film Indie Itu Gampang, Katarsis, Bandung, 2003;

Departemen Agama RI, Al-Quran Dan Terjemahannya, Yayasan Penyelenggara Terjemahan, Jakarta, 1984;

H.Yunahar Ilyas, Kulia Akhlak, Pustaka Pelajar Offset, Yogyakarta, 2012, Jalaaludin Rahmat, Jurnalistik Televisi, Alumni, Bandung, 1980;

Rahmat Sudirman, Surat Kabar Lampung Post, terbitan,tanggal 2 Agustus 1997;

Onong Uchyana Effendy, Ilmu Teori dan Filsafat Komunikasi, PT. Citra Aditya Bakti, Bandung,1993;

Suharsimi Arikonto, Prosedur Penelitian Suatu Pendekatan Praktek, Edisi Revisi VI, Rienika Cipta, Jakarta, 2006;

Wahyuni. J.B, Media Komunikasi Masa Televisi, Alumni, Bandung, 1986;

Zakiyah Daradjat, Ilmu Jiwa Agama, Bulan Bintang, Jakarta, 1990;

Zulkifli, Psikologi Perkembangan, Remaja Rosdakarya Ofset, Bandung, 2003. 